\title{
NILAI-NILAI PENDIDIKAN DALAM SURAT AD DHUHA
}

\author{
Ari Abi Aufa ${ }^{1}$ \\ Institut Agama Islam Sunan Giri Bojonegoro \\ aufa@sunan-giri.ac.id
}

\begin{abstract}
Abstrak
This articel discuse about values educations in surah Ad Dhuha, Surat Ad Dhuha cannot use the results of the translation only or based on the final text. If the surah is understood using a literal translation or just a text from a verse, the results of the understanding obtained may be confused. Education values in surah Ad dhuha we will find a lot in interpretations, in the discussion verse by verse then we will gain an understanding of the meaning contained in the surah ad dhuha, the educational values that we can get as first, do not dissolve in worldly affairs because worldly affairs can defeat, secondly, the afterlife of pleasure is more important than world affairs and therefore do not get lost in temporary world life. Third, apply gentleness to orphans, do not act harshly even rebuke him, fourth, always remember the favors of God that have been given and do not associate partners.
\end{abstract}

\section{Keyword: Nilai-Nilai Pendidikan, Surat Ad dhuha}

\section{A. PENDAhuluan}

Memahami Al-Qur'an tidak bisa hanya menggunakan hasil terjemahan atau hanya berdasar pada teks dhahirnya saja. Apabila Al-Qur'an dipahami menggunakan terjemahan harfiah atau teks dhahir ayat saja maka hasil pemahaman yang diperoleh bisa jadi akan rancu. Al-Qur'an sebagai teks suci, harus dipahami menggunakan piranti keilmuan yang lengkap, salah satunya adalah menggunakan ilmu tafsir. Baru-baru ini viral ceramah seorang ustadz yang "dengan berani" menyatakan bahwa Muhammad (tidak menggunakan kata "Nabi") sesat. la beralasan bahwa pernyataannya mengacu pada ayat 7 surat Al-Dhuha yang berbunyi (ووجدك ضالا فهدى). Apakah dapat dibenarkan pendapat di atas, bahwa Nabi Muhammad sesat? ${ }^{2}$ Dalam kajian ilmu tafsir, penafsiran

\footnotetext{
${ }^{1}$ Dosen Magister Pendidikan Agama Islam Institut Agama Islam Sunan Giri Bojonegoro

2 Ada tiga hal yang perlu dijelaskan untuk menanggapi perihal pernyataan sang ustadz, yaitu: (1) menganalisis kata "ضالا" dari sisi bahasa (etimologi), (2) mengalisis kata "ضالا" lewat penafsiran ayat Al-Qur'an dengan ayat Al-Qur'an yang lain, dan (3) etika terhadap Nabi. Pertama, secara bahasa, apabila ada pohon di 
Al-Qur'an dilakukan dengan empat metode. Pertama, menafsirkan ayat Al-Qur'an dengan ayat Al-Qur'an yang lain. Kedua, menafsirkan Al-Qur'an dengan hadits Nabi. Ketiga, menafsirkan ayat Al-Qur'an dengan qaul (perkataan) sahabat. Keempat, menafsirkan ayat Al-Qur'an dengan qaul tabi'in. Dalam hal ini, maka tidak boleh seorang menafsirkan Al-Qur'an, mengutarakan makna Al-Qur'an tanpa memahami keempat metode di atas, apalagi hanya berdasarkan terjemahan. Apabila ia berani menafsirkan Al-Qur'an tanpa menggunakan keempat metode di atas dan tidak memiliki seperangkat keilmuan pendukung, dalam tulisan ini akan dibahas tentang surat ad dhuha yang sarat akan nilai-nilai pendidikan.

\section{B. PEMBAHASAN}

\section{Definisi Ad Dhuha}

Adh-Dhuha adalah siang secara keseluruhan. Karena kalimat selanjutnya adalah "wal-laili idza sajaa" artinya malam ketika gelap, berarti lawan waktu Dhuha yang disebut pertama. ${ }^{3}$ dalam Makna Adh-Dhuha sendiri ada empat pendapat yaitu terangnya siang, depannya siang, awal siang ketika matahari mulai meninggi, dan ada pula yang berpendapat seluruh waktu siang disebut Adh-Dhuha. ${ }^{4}$

Sedangkan ayat,

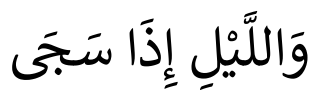

Dan demi malam ketika "sajaa". Maksud "سَبَى" sajaadi sini adalah "سَكَنَ"sakana, yaitu tenang.

'Atha' mengatakan bahwa yang dimaksud " adalah jika (siang) telah tertutupi gelap. Juga dikatakan yang hampir sama oleh Ibnul 'Arabi, Al-Ashma'i, Al-

tengah-tengah padang sahara atau di tengah-tengah hutan belantara tanpa ada pohon lain yang menyandinginya, maka pohon tersebut dikatakan "dhallah". Artinya, Nabi sebelum diangkat menjadi seorang rasul, beliau banyak menyaksikan kaumnya menyembah berhala dan perilaku syirik lainnya, sementara beliau sendiri sedang dalam keadaan sendirian (tidak mengikuti perilaku mereka) dan kebingungan tanpa ada orang lain yang menyertainya. Maka, dalam ayat tersebut digunakan diksi kata "dhal" sesuai dengan keadaan Nabi yang menjauh dan tidak mengikuti perilaku mereka, bukan berarti sesat kebalikan kata hidayah. Dengan demikian, maka menurut Imam Sayyid Al-Tanthawiy, makna dari (ووجدك ضالا فهدى) adalah "tidak ada seorang pun yang mengikuti agamamu, engkau seorang diri tidak ada yang menyertaimu, maka sebab engkau mereka mendapat hidayah menuju kepada-Ku." Kata "ضالا" juga berarti bingung, bukan sesat kebalikan kata hidayah.

${ }^{3}$ Imam Asy-Syaukani, Fath Al-Qadir, 1:611.

${ }^{4}$ Lihat Zaad Al-Masiir, 9:159. 
Hasan Al-Bashri. Sa'id bin Jubair menyatakan "ketika malam telah tiba. Mujahid menyatakan bahwa "maksudnya adalah ketika malam telah istawa (telah lurus). Namun pendapat pertama yang menyatakan "artinya "ketika malam itu tenang", yaitu datang gelap dan tidak bertambah gelapnya lagi setelah itu, itu yang lebih dikuatkan oleh Imam Asy-Syaukani: ${ }^{5}$

Adapun "سَكَكَنَ" bermakna sakana ada dua makna: (1) ketika malam tenang, (2) ketika ada makhluk yang muncul pada waktu malam. Kalimat “ (1والضُّحَى (1) 2) adalah kalimat sumpah (al-qasam). Sedangkan jawab al-qasam (jawab sumpah) ada pada kalimat “" "مَاوَدََّعَكَ رَبُكَكَ", Rabbmu tidak meninggalkanmu, maksudnya adalah Allah tidak meninggalkan Nabi Muhammad sebagaimana seseorang yang berpisah meninggalkan barang. Kata "قَّلى " artinya "أبغض" (membenci), sehingga maksud ayat "مَا وَدَّعَكَ رَبُّكَ وَمَا قَلَى adalah Allah tidak meninggalkan dan tidak membencimu.

Kemudian pada ayat,

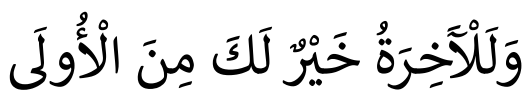

"Dan sesungguhnya hari kemudian itu lebih baik bagimu daripada yang sekarang (permulaan)." (Dan sesungguhnya akhir itu lebih baik bagimu), maksudnya kehidupan di akhirat itu lebih baik bagimu, karena di dalamnya terdapat kemuliaan-kemuliaan bagimu (dari permulaan) dari kehidupan duniawi.

Kehidupan dunia ini hanya bagaikan mata'ul ghurur (kesenangan yang menipu) sebagaimana disebutkan dalam ayat lainnya,

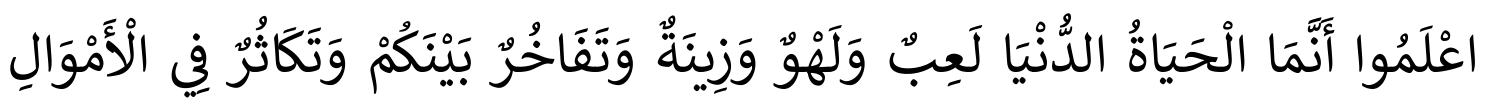

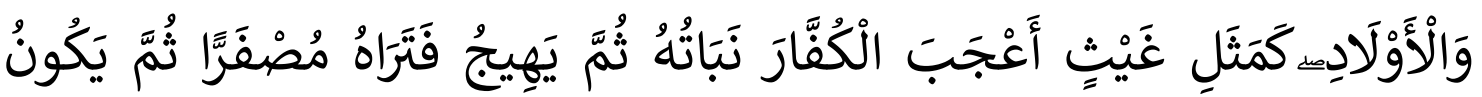

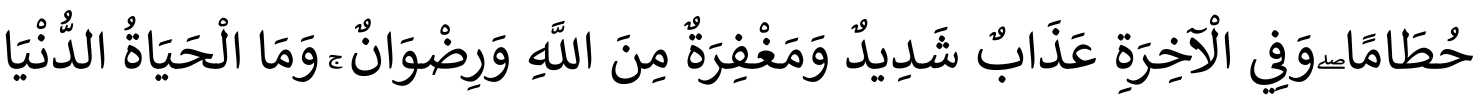

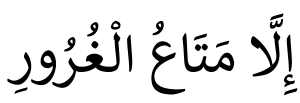

"Ketahuilah, bahwa sesungguhnya kehidupan dunia ini hanyalah permainan dan suatu yang melalaikan, perhiasan dan bermegah-megah antara kamu serta berbangga-

${ }^{5}$ Imam Asy-Syaukani, 1:611.

Al-Aufa: Jurnal Pendidikan dan Kajian Keislaman Volume 01 Nomor 01 Edisi Juli- Desember 2019 
banggaan tentang banyaknya harta dan anak, seperti hujan yang tanam-tanamannya mengagumkan para petani; kemudian tanaman itu menjadi kering dan kamu lihat warnanya kuning kemudian menjadi hancur. Dan di akhirat (nanti) ada azab yang keras dan ampunan dari Allah serta keridhaan-Nya. Dan kehidupan dunia ini tidak lain hanyalah kesenangan yang menipu." (QS. Al-Hadid: 20).

Dalam Tafsir Al-Jalalain disebutkan bahwa manusia terlalu sibuk dengan dunianya. Padahal hal-hal tadi (anak dan harta) bisa mendukung pada akhirat. Dunia itu membuat kita kagum layaknya petani yang kagum pada tanaman. Padahal tanaman itu nantinya kering dan menguning, lalu hancur menjadi keropos dan tertiup angin. Yang mementingkan dunia dari akhirat, baginya siksa yang keras. Padahal dunia itu tidak lain hanyalah kesenangan yang menipu. ${ }^{6}$

Imam Ibnu Katsir rahimahullah berkata bahwa Allah Ta'ala menjadikan permisalan kehidupan dunia dengan perhiasan yang akan fana (sirna) dan kenikmatan yang akan hilang. Dunia itu diibaratkan dengan ghaits yaitu hujan yang datang setelah sekian lama tak kunjung turun. Sebagaimana yang disebutkan dalam ayat,

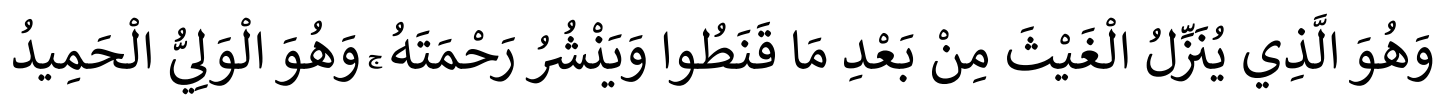

"Dan Dialah Yang menurunkan hujan sesudah mereka berputus asa dan menyebarkan rahmat-Nya. Dan Dialah Yang Maha Pelindung lagi Maha Terpuji." (QS. Asy-Syura: 28)

Ibnu Katsir rahimahullah juga menyatakan para petani itu begitu takjub pada tanaman yang tumbuh karena hujan tadi. Sama halnya dengan orang kafir ketika memandang dunia. Orang kafir itu begitu semangat pada dunia, hati pun condongnya pada dunia. Padahal tanaman tadi itu bisa menguning, setelah sebelumnya begitu hijau dan enak dipandang mata. Kemudian akhirnya tanaman itu hancur dan kering. ${ }^{7}$

Ibnu Katsir rahimahullah mengatakan, dunia itu awalnya layaknya pemuda kemudian beranjak menjadi berumur antara 30-50 tahun (kuhulan), lalu menjadi sepuh (keriput dan buruk rupa). Demikian pula fisik manusia dilihat dari umurnya. Di waktu syabab (pemuda) begitu semangat, begitu semangat dan gesit serta enak

\footnotetext{
${ }^{6}$ Jalaluddin as-Suyuthi dan Jalaludin al Mahali, Tafsir Jalalain, (Jakarta: Ummul Quro, 2018), 551.

7 Jalaluddin as-Suyuthi dan Jalaludin al Mahali, 552.
} 
dipandang. Lalu berubah menjadi kuhulan (tua), sebagian kekuatannya menjadi hilang. Lantas ia beralih sepuh yang kekuatannya terus melemah. Itulah yang disebutkan pula dalam ayat lainnya,

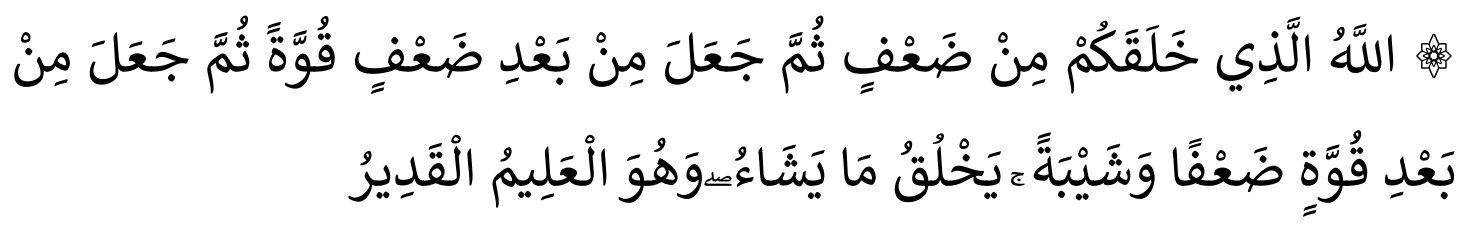

"Allah, Dialah yang menciptakan kamu dari keadaan lemah, kemudian Dia menjadikan (kamu) sesudah keadaan lemah itu menjadi kuat, kemudian Dia menjadikan (kamu) sesudah kuat itu lemah (kembali) dan beruban. Dia menciptakan apa yang dikehendaki-Nya dan Dialah Yang Maha Mengetahui lagi Mahakuasa." (QS. Ar-Ruum: 54). ${ }^{8}$

Permisalan ini menunjukkan akan sirnanya dunia, sedangkan akhirat akan kekal abadi. Sehingga seharusnya kita semangat untuk menggapai akhirat. Di akhirat yang ada hanyalah siksa yang pedih, ataukah ampunan Allah.

Dalam ayat selanjutnya disebutkan,

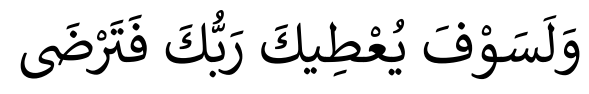

"Dan kelak Tuhanmu pasti memberikan karunia-Nya kepadamu, lalu (hati) kamu menjadi puas."

Dalam Tafsir Al-Jalalain disebutkan, (Dan kelak Rabbmu pasti memberimu) di akhirat berupa kebaikan-kebaikan yang berlimpah ruah (lalu kamu menjadi puas) dengan pemberian itu. Maka Rasulullah shallallahu 'alaihi wa sallam bersabda, "Kalau begitu mana mungkin aku puas, sedangkan seseorang di antara umatku masih berada di neraka." Sampai di sini selesailah Jawab Qasam, yaitu dengan kedua kalimat yang dinisbatkan sesudah dua kalimat yang dinafikan.

Dalam Tafsir Al-Qur'an Al-'Azhim, Ibnu Katsir rahimahullah berkata di negeri akhirat, Allah memberi pada Muhammad karunia sampai ia ridha pada umatnya. Di antara yang diberi adalah karamah, juga termasuk sungai Al-Kautsar. Dalam riwayat dari Ibnu 'Abbas disebutkan bahwa kelak akan diberikan di surga sejuta istana, di mana setiap istana tersebut memiliki istri dan pembantu. Yang terakhir ini

\footnotetext{
8 Jalaluddin as-Suyuthi dan Jalaludin al Mahali, 553.
} 
diriwayatkan oleh Ibnu Jarir dari jalurnya, sanadnya sahih sampai Ibnu 'Abbas. Hal ini disebutkan oleh Ibnu 'Abbas tentu berdasarkan dalil. ${ }^{9}$

Pengertian lainnya pula yang disebutkan dalam Tafsir Al-Qur'an Al-'Azhim, bentuk karunia pada Nabi Muhammad shallallahu 'alaihi wa sallam adalah anggota keluarganya tidak ada yang dimasukkan dalam neraka. Demikian yang dikatakan oleh As-Sudi, dari Ibnu 'Abbas sebagaimana diriwayatkan oleh Ibnu Jarir dan Ibnu Abi Hatim.

Tafsiran lainnya pula menyebutkan bahwa bentuk karunia pada Nabi Muhammad shallallahu 'alaihi wa sallam adalah syafaat. Hal ini sebagaimana dikatakan oleh Al-Hasan Al-Bashri, juga dinyatakan oleh Abu Ja'far Al-Baqir.

Yang tepat sebagaimana disebutkan dalam At-Tafsir Al-Muyassar, kelak Allah akan memberikan kepada Muhammadshallallahu 'alaihi wa sallam di akhirat berbagai nikmat, lantas beliau akan ridha dengan yang demikian. Pernyataan yang sama juga disebutkan oleh Syaikh As-Sa'di rahimahullah dalam kitab tafsirnya.

Kemudian setelah itu dirinci berbagai nikmat yang diberikan kepada Nabi kita Muhammad shallallahu 'alaihi wa sallam,

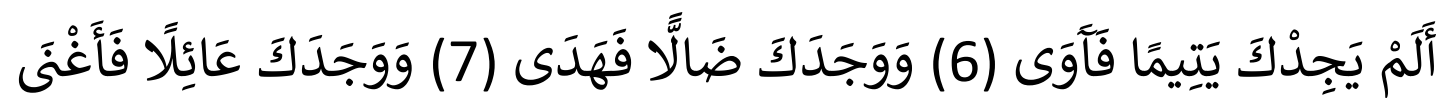

"Bukankah Allah mendapatimu sebagai seorang yatim, lalu Dia melindungimu? Dan Allah mendapatimu sebagai seorang yang bingung, lalu Dia memberikan petunjuk. Dan Allah mendapatimu sebagai seorang yang kekurangan, lalu Dia memberikan kecukupan."

Dalam At-Tafsir Al-Muyassar disebutkan, bukankah sebelumnya Allah menjadikanmu dalam keadaan yatim, lantas Allah melindungi dan memeliharamu. Sebelumnya juga Nabi Muhammad dalam keadaan tidak tahu kita dan tidak tahu iman, lantas Allah mengajarkan pada Muhammad ilmu yang ia belum mengetahui, lantas diberi taufik pula pada bagusnya amal. Juga sebelumnya Muhammad dalam

\footnotetext{
${ }^{9}$ Jalaluddin as-Suyuthi dan Jalaludin al Mahali, 556.
} 
keadaan fakir, lantas diberikan rezeki dan berikan kecukupan dengan sifat qana'ah dan sabar. ${ }^{10}$

Syaikh As-Sa'di rahimahullah menerangkan tentang ayat "Bukankah Allah mendapatimu sebagai seorang yatim, lalu Dia melindungimu", maksudnya Allah mendapatimu dalam keadaan tidak memiliki ibu dan ayah, di mana ibu dan ayah Nabi shallallahu 'alaihi wa sallam meninggal dunia ketika itu ia tidak merawat dirinya sendiri, namun Allah yang melindungi dan memelihara beliau. Kakeknya 'Abdul Muththalib yang merawatnya setelah itu. Ketika kakeknya meninggal dunia, dilanjutkan pemeliharaan beliau oleh pamannya Abu Thalib. Sampai Allah terus menerus menolong beliau.

Maksud ayat,

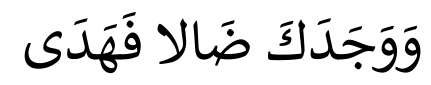

"Dan Dia mendapatimu sebagai seorang yang bingung, lalu Dia memberikan petunjuk."

Syaikh As-Sa'di rahimahullah mengatakan, "Allah mendapatimu (wahai Muhammad) dalam keadaan tidak mengetahui Al-Qur'an, tidak mengetahui iman, lalu diajarkan kepadamu yang engkau belum ketahui. Akhirnya engkau mendapatkan taufik sehingga baik dalam amalan dan akhlak."

Ada juga tafsiran lainnya yang mengatakan, "Ketika kecil Nabi Muhammad shallallahu 'alaihi wa sallam tersesat di celah-celah kota Makkah akhirnya Allah mengembalikan beliau pada kakeknya 'Abdul Muththalib." Demikian ini pendapat yang diriwayatkan dari Ibnu 'Abbas sebagaimana disebutkan dalam tafsir Zaad Al-Masiir.

Sedangkan maksud ayat "Dan Dia mendapatimu sebagai seorang yang kekurangan, lalu Dia memberikan kecukupan" yaitu Muhammad didapati dalam keadaan fakir, kemudian Allah taklukkan bagi Muhammad berbagai negeri yang di situ didapati perbendaharaan harta dan hasil bumi.

\footnotetext{
${ }^{10}$ Tafsir al Muyassar (Jakarta: Darul Haq, tth) 774.
} 
Yang dimaksud diberi kecukupan di sini adalah Allah membuat Muhammad ridha terhadap rezeki. Inilah pendapat As-Saib, juga dipilih Al-Fara'. Al-Fara' berkata,

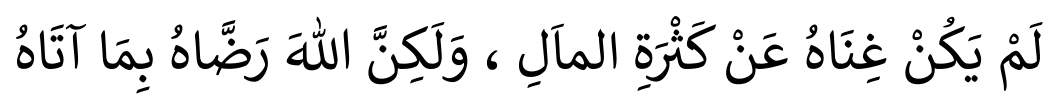

"Ghina (kaya)-nya Nabi kita Muhammad itu bukan dengan banyaknya harta. Akan tetapi beliau rida terhadap rezeki yang diberi."11

Setelah itu barulah disebutkan, "Sebab itu, terhadap anak yatim janganlah kamu berlaku sewenang-wenang. Dan terhadap orang yang minta-minta, janganlah kamu menghardiknya.Dan terhadap nikmat Rabbmu, maka hendaklah kamu siarkan."

Di sini maksudnya adalah jika Allah yang telah menghilangkan darimu berbagai kekurangan, yang telah memberikan kecukupan kepadamu, yang telah melindungi, menolong, hingga memberi petunjuk padamu, maka balaslah berbagai nikmat tersebut dengan bersyukur kepada-Nya.

Oleh karena itu, terhadap anak yatim janganlah bertindak kasar dan menyakitinya. Anak yatim itu dimuliakan dan diberi apa yang memudahkan mereka. Hendaklah kita lakukan seperti apa yang kita senang jika anak-anak kita diperlakukan seperti itu pula.

Adapun yang meminta-minta janganlah dihardik dan diperlakukan dengan akhlak yang jelek. Harusnya pada yang meminta-minta diberi kemudahan dan dibalas dengan yang makruf serta berbuat baik. Demikian penjelasan dari Syaikh AsSa'di rahimahullah.

\section{Menyebut-nyebut nikmat}

Berikut beberapa pendapat ulama mengenai ayat,

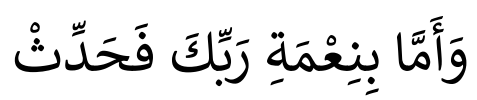

"Dan terhadap nikmat Tuhanmu, maka hendaklah kamu siarkan." (QS. Adh Dhuha: 11).

\footnotetext{
${ }^{11}$ Ibnu Qoyyim Al Jauziyah, Zaad Al Masiir, (Dar Ibnu Hazm, Beirut - Lebanon, 2002), 159.
} 
Dari 'Amr bin Syu'aib, dari ayahnya, dari kakeknya, ia berkata bahwa Rasulullah shallallahu 'alaihi wa sallam bersabda,

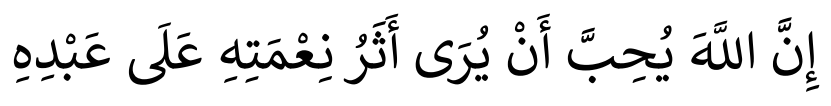

"Sesungguhnya Allah suka melihat tampaknya bekas nikmat Allah pada hambaNya." (HR. Tirmidzi no. 2819 dan An Nasai no. 3605. Al Hafizh Abu Thohir mengatakan bahwa hadits ini sahih).

Syaikh Muhammad Al Utsaimin menerangkan bahwa hendaklah setiap orang bersederhana dalam setiap aktivitasnya. Hendaklah ia bersederhana dalam pakaian, makan, dan minum. Namun jangan sampai ia menyembunyikan nikmat Allah. Karena Allah amatlah suka jika melihat bekas nikmat pada hamba-Nya.

Jika nikmat tersebut berupa harta, maka Allah sangat senang jika hamba memanfaatkan nikmat tersebut untuk berinfak, bersedekah, dan menolong dalam kebaikan.

Jika nikmat tersebut berupa ilmu, maka Allah sangat senang jika ilmu tersebut diamalkan sehingga baik ibadah dan muamalahnya, juga ilmu tersebut disebar dengan dakwah dan mengajari orang lain.

Jika malah sebaliknya, saat Allah sudah memberikan nikmat harta sehingga mampu sebenarnya membeli pakaian, kok malah ia keluar di hadapan orang lain dalam keadaan fakir (seakan tak punya apa-apa). Ini hakekatnya menolak atau menentang nikmat Allah. Sama halnya jika orang diberi harta, lantas ia tidak memanfaatkannya untuk infak atau memenuhi kewajiban dari harta.

Begitu pula dengan nikmat ilmu, kalau tidak dimanfaatkan untuk menambah ibadah, khusu' dalam ibadah atau baik dalam muamalah, atau tidak dimanfaatkan untuk mengajarkan orang lain, maka ini pun tanda menyembunyikan nikmat Allah. ${ }^{12}$

\section{KESIMPULAN}

12 Imam, An Nawawi, Syarh Riyadhus Sholihin, (Jakarta: Darul Haq), 318-319. 
Dari pemaparan diatas dapat disimpulkan bahwa nilai-nilai pendidikan dalam surat Ad dhuha akan banyak kita temukan dalam tafsir-tafsir klasik dan kontemporer, dalam memahami ayat demi ayat maka akan kita dapatkan pemahaman tentang makna yang terkandung dari surat ad dhuha, nilai-nilai pendidikan yang dapat kita dapatkan adalah pertama, jangan larut dalam urusan duniawi karena urusan duniawai bisa menipu, kedua, kebaikan akhirat lebih utama daripada urusan dunia oleh karena itu jangan sampai tersesat dalam kehidupan dunia yang sementara. Ketiga, berlaku lemah lembutlah terhadap anak yatim, jangan belaku kasar apalagi menghardiknya, keempat, ingatlah selalu nikmat-nikmat Allah yang telah diberikan dan jangan menyekutukannya. 


\section{DAFTAR PUSTAKA}

Imam Asy-Syaukani, Fath Al-Qadir, Fath al-Qadīr al-Jāmi' Bayna Fanny al-Riwāyah wa alDirāyah fĩ llmi al- (Beirut - Lebanon,tth.

Lihat Zaad Al-Masiir, Dar Ibnu Hazm, Beirut - Lebanon, 2002

Jalaluddin as-Suyuthi dan Jalaludin al Mahali, Tafsir Jalalain, Jakarta: Ummul Quro, 2018.

Tafsir al Muyassar, Jakarta: Darul Haq, tth) 774.

Ibnu Qoyyim Al Jauziyah, Zaad Al Masiir, Dar Ibnu Hazm, Beirut - Lebanon, 2002.

Imam, An Nawawi, Syarh Riyadhus Sholihin, Jakarta: Darul Haq 